\title{
MIR298 wt Allele
}

National Cancer Institute

\section{Source}

National Cancer Institute. MIR298 wt Allele. NCI Thesaurus. Code C82177.

The human MIR298 wild-type allele is located in the vicinity of 20 q13.32 and is approximately 87 bases in length. This allele, which encodes MIR298 pre-miRNA, plays a role in the regulation of gene expression. Alteration in the expression of this gene is associated with development of Alzheimer's disease. 